\title{
可変構造パラメータを有する適応構造システムにおける 自己同定可能性指標*
}

\author{
仙場 淳 彦*1, 古 谷寛*2

\section{Criterion for Self-identification of Adaptive Structure Systems with Variable Structural Parameters}

\author{
Atsuhiko SENBA*3 and Hiroshi FURUYA \\ ${ }^{* 3}$ Department of Information Engineering, Nagoya University, \\ Furo-cho, Chikusa-ku, Nagoya-shi, Aichi, 464-8603 Japan
}

\begin{abstract}
The purpose of this study is to propose a criterion for evaluating a capability of variable structural parameters in adaptive structure systems to implement the self-identification with the variable matrices method. The criterion is derived by analyzing a set of the Modal Assurance Criterion corresponding to two independent mode shapes, which are changed by the variable structural parameters. To demonstrate the use of the criterion, we conduct parameter identification experiments with a cantilevered beam structure with a variable stiffness system. In the experiments, an extended form of the variable matrices method is used to identify unknown bending stiffness and mass per unit length of the beam. The results show clear relation between the identification accuracy and the proposed criterion, and therefore the criterion is useful for evaluating the capability of the variable parameters to change the modal properties effectively.
\end{abstract}

Key Words: Adaptive Structure, Sensitivity Analysis, Modal Analysis, Identification, Selfidentification, Variable Structural Parameters, Modal Assuarance Criterion

\section{1. 序論}

外的環境変化や目的に応じて様々な適応性を持つ適 応構造物 ${ }^{(1)}$ が提案されて以来, 約 20 年余りの間に, 地 上構造物及び機械においてスマート化や知的化を行う 様々な構造概念および構造システムが提案されてきた. 何れの概念も構造, センサ, アクチュエータ等を一体化 することで性能向上や機能の創出が行われる. 本研究 では特に, 構造内部に可変構造パラメータを有するシ ステムに着目し適応構造システムと定義する.

機械や構造物の数学モデルの慣性, 减衰, 剛性行列等 の特性行列を, 振動試験データを用いて修正するモデ ル更新手法は, 計算機の処理能力向上に応じて 1990年 代以降, 特に注目されている ${ }^{(2)}$. また, 土木構造物の老 朽化や人為的な非破壊検査の実施が困難なプラント及 び宇宙構造物等の損傷位置や程度を振動特性から推定 する損傷同定あるいは構造ヘルスモニタリングに関す

* 原稿受付 2006 年 7 月 18 日

*1 正員, 名古屋大学大学院情報科学研究科(䡤 464-8603 名古 屋市千種区不老町).

*2 正員, 東京工業大学大学院総合理工学研究科(患 226-8502 横浜市緑区長津田 4259-G3-6)

E-mail : senba@nuae.nagoya-u.ac.jp
る研究が活発に行われている(3).

モデル更新ならびに特性行列同定の分野における 様々な研究がなされてきた ${ }^{(4)}$ (5).一般に, 末知数の数に 対して実験的に計測可能なデータに含まれる情報量の 不足が課題となる.このため, モデル更新における情報 不足に対して,データ取得条件の改善を目的とした振 動試験に関する研究が行われてきた. 例えば, Nalitolela らは, 質量や剛性を付加し, 振動デー夕量の増加を図る 振動試験法を提案しており, 提動境界条件振動試験と 呼ばれている ${ }^{(6)}$. しかし, 構造内部に予め可変構造パ ラメータが組み込まれた適応構造システムやスマート 構造物のための体系的な同定理論の構築は未だ十分に 行われていない.

自己同定の概念は, 適応構造システムが有する様々 な可変構造パラメータを変化させることにより同定に 必要な情報を増加させ, 動力学特性を同定する概念で あり, 自己同定に基づく特性行列同定法として可変行 列同定法を提案してきた ${ }^{(7)}$.これまで構造物に内臓さ れた各種の可変デバイスによる可変剛性 ${ }^{(8)}$ や可変慣 性 ${ }^{(9)}$ といった物理パラメータ可変型, 及び可変形状卜 ラス (VGT) に代表される幾何形状可変型の適応構造 
物における可能性を明らかにしてきた ${ }^{(10)}$. しかしなが ら,自己同定の実現性を実証した例は報告されていな い. また, 可変構造パラメータの適切な制御方針や可変 構造パラメータとして用いる各種のデバイスの配置の 適切性を評価する指標等が必要であると考えられる。

自己同定の実現性を実証するために, 本研究では柔 軟梁と可変剛性バネからなる可変剛性システムを扱う. 本システムの曲げ剛性や質量等を同定対象として, 自 己同定の概念に基づく構造パラメータ同定を行う. 筆 者らがこれまで提案してきた可変行列同定法 ${ }^{(7)}$ は, 梁 のような連続体の同定には直接対応していないため, 可変行列同定法を梁の構造パラメータ同定に適した形 式に拡張する必要がある。

以上の背景から本研究の目的は, 可変構造パラメー 夕を有する適応構造システムの自己同定能力を定量的 に評価する自己同定可能性指標の提案を行うことであ る. 加えて, 従来, 数值実験により可能性が示されてき た自己同定の実現性を付加バネと柔軟梁からなる可変 剛性システムにより実証する.ささらに有限要素モデル を用いた数值実験を行い, 指標値と同定精度の関倸を 考察し, 提案する指標の有効性を明らかにする.

\section{2. 自己同定可能性指標の導出}

可変行列同定法による自己同定では, 可変構造パラ メータにより振動モードの固有值, 固有ベクトルが独 立に変化可能であることが必要である ${ }^{(7)}$. 本節では, 可 変構造パラメータにより変化する固有ベクトルの独立 性を定量的に扱い,それを自己同定能力として評価す る自己同定可能性指標を提案する.

2.1 自己同定可能性指標 自己同定可能性指標 を,二つの異なるベクトルの独立性及び一致度を計る ために広く用いられている Modal Assurance Criterion $(M A C)$ 数に基づき導出する. まず, その動力学特性を 線形システムとして表せる適応構造システムにおいて, 適当な制御入力により構造内部の可変構造パラメータ を制御可能であると仮定する.このとき制御入力によ $\eta, i$ 次固有ベクトルが, 初期值 $\tilde{\mathbf{X}}_{i, j}$ から $\tilde{\mathbf{X}}_{i, j+1}$ に変化 したとするとき, 二つの固有ベクトルの $M A C$ 数は,

$$
\operatorname{MAC}_{j, j+1}=\frac{\left|\tilde{\mathbf{X}}_{i, j}^{T} \tilde{\mathbf{X}}_{i, j+1}\right|^{2}}{\left(\tilde{\mathbf{X}}_{i, j}^{T} \tilde{\mathbf{X}}_{i, j}\right)\left(\tilde{\mathbf{X}}_{i, j+1}^{T} \tilde{\mathbf{X}}_{i, j+1}\right)},
$$

と表され, 右辺の值は次式を満たす.

$$
0 \leq \frac{\left|\tilde{\mathbf{X}}_{i, j}^{T} \tilde{\mathbf{X}}_{i, j+1}\right|^{2}}{\left(\tilde{\mathbf{X}}_{i, j}^{T} \tilde{\mathbf{X}}_{i, j}\right)\left(\tilde{\mathbf{X}}_{i, j+1}^{T} \tilde{\mathbf{X}}_{i, j+1}\right)} \leq 1 .
$$

$M A C_{j, j+1}=0$ の時, 二つの固有ベクトルは直交し, 一 方, $M A C_{j, j+1}=1$ の時, 二つのベクトルは平行であり
従属である.したがって, 自己同定のためにはできるだ けMACは 0 に近い方が良い。

同様に, $i$ 次モード固有ベクトルを複数回の構造パラ メータ変化により $m$ 回変化させたとき, $m$ 個の固有心゙ クトルが得られた場合には異なる二つの固有ベクトル の組の $M A C$ 数の和は,

$$
0 \leq \frac{1}{2} \sum_{j=1}^{m} \sum_{k=1}^{m} M A C_{j, k} \leq \frac{m(m-1)}{2},(j \neq k)
$$

となるので,これらの平均的な值として次式で自己同 定可能性指標 (Criterion for Self-identification: CSI) を 定義する.

$$
C S I=\frac{\frac{m(m-1)}{2}-\frac{1}{2} \sum_{j=1}^{m} \sum_{k=1}^{m} M A C_{j, k}}{\frac{m(m-1)}{2}} .(j \neq k)
$$

$C S I$ は 0 から 1 の值をとり, $C S I=1$ に近いほど得られ た $m$ 個の固有ベクトルは自己同定に適した組み合わ せであることになる.

また, 序論で触れたように, 本稿で新たに提案する柔 軟梁のための可変行列同定法では, 固有ベクトルだけ でなく,その積分值を含む係数行列の数值的特性が自 己同定の精度に影響を与える. 従って, 式 (4) を拡張し て,一般的な倸数行列のための指標を合わせて提案す る.これを挔張自己同定可能性指標 (Extended Criterion for Self-identification: $E C S I)$ と呼ぶ. 未知構造行列あ るいは未知ベクトルにかかる係数行列を $\mathbf{A}$ とすると， 式 (4) と同様の形式で, ECSI は以下のように表せる.

$$
E C S I=\frac{\frac{m(m-1)}{2}-\frac{1}{2} \sum_{j=1}^{m} \sum_{k=1}^{m} \frac{\left|\mathbf{A}_{i, j}^{T} \mathbf{A}_{i, k}\right|^{2}}{\left(\mathbf{A}_{i, j}^{T} \mathbf{A}_{i, j}\right)\left(\mathbf{A}_{i, k}^{T} \mathbf{A}_{i, k}\right)}}{\frac{m(m-1)}{2}} .
$$

\section{3. 可変剛性を有する柔軟片持ち梁の自己同定法}

本章では, 線形離散システムのための従来の可変行 列同定法 ${ }^{(7)}$ を, 連続体である梁のパラメータ同定法に 拡張する. 図 1 に示すように, 鉛直下向きに一端固定 された柔軟片持ち梁の一部にバネを取り付け,これを 可変剛性システムとして扱う. 付加するバネは, 梁の一 点で梁に対し垂直に固定され, 微小変位の範囲で面外 変位に対し線形バネとして働く．また, バネの質量は, 梁に比べて無視できるとする.

柔軟梁の振動特性変化を生じさせる可変構造パラ メータの制御入力は, $m$ 通りに変化可能な可変バネ定 数とする.

$$
\mathbf{u}_{j}=k_{v j}(x) \cdot(j=1,2, \cdots, m)
$$

次に, 片持ち梁の固定点から長手方向の座標を $x$, 面外 変位を $v(x, t)$, 重力定数を $g$, 単位長さ質量を $\rho A(x)$, 曲 
げ哃性を $E I(x)$ とおく.ここではオイラー梁を仮定す ると, 可変剛性を陽に含み, 重力を考慮した梁の運動方 程式が次式のように表せる.

$$
\begin{gathered}
\rho A(x) \frac{\partial^{2} v(x, t)}{\partial t^{2}}+\frac{\partial^{2}}{\partial x^{2}}\left(E I(x) \frac{\partial^{2} v(x, t)}{\partial x^{2}}\right) \\
-\frac{\partial}{\partial x}\left(\int_{x}^{L} \rho A(x) g d x \frac{\partial v(x, t)}{\partial x}\right)+k_{v j}(x) v(x, t)=f(t) .
\end{gathered}
$$

ここで, $t$ は時間を表す. 式 (7)の解をモード形状, $w_{i j}(x)$, モード座標, $q_{i}(t)$ の積として, $v(x, t)=w_{i j}(x) q_{i}(t)$ と表 すことができ, 外力の存在しない場合を仮定すると,以 下のような固有值問題が導かれる.

$$
\begin{aligned}
& -\lambda_{i, j} \rho A(x) w_{i j}(x)+\frac{\partial^{2}}{\partial x^{2}}\left(E I(x) \frac{\partial^{2} w_{i j}(x)}{\partial x^{2}}\right) \\
& -\frac{\partial}{\partial x}\left(\int_{x}^{L} \rho A(x) g d x \frac{\partial w_{i j}(x)}{\partial x}\right)+k_{v i j}(x) w_{i j}(x)=0, \\
& (i=1,2, \cdots, n)
\end{aligned}
$$

ここで, $\partial^{2} q_{i}(t) \partial t^{2}=-\lambda_{i j} q_{i j}(t)$ であり, $i, j, \lambda_{i}$ はそれぞ れ, モード炊数, 制御入力变化の次数, $i$ 次モードの固有 值である. 式 (8) より, $j$ 番目制御入力に対応した $i$ 次 モードの等価質量 (慣性エネルギ), $\tilde{k}_{i j}$, 等価剖性 (歪エ ネルギ， $\tilde{m}_{i j}$ は次式で表せる.

$$
\begin{aligned}
\tilde{k}_{i j} & =\frac{1}{2} \int_{0}^{L}\left[E I(x)\left\{\frac{\partial^{2} w_{i j}(x)}{\partial x^{2}}\right\}^{2}\right. \\
& \left.+\int_{x}^{L} \rho A(x) g d x\left\{\frac{\partial w_{i j}(x)}{\partial x}\right\}^{2}+k_{v j}(x) w_{i j}^{2}\right] d x,(9) \\
\tilde{m}_{i j} & =\frac{1}{2} \int_{0}^{L} \rho A(x) w_{i j}^{2}(x) d x .
\end{aligned}
$$

あるいは, $\rho A(x), E I(x), k_{v j}$ を分離した形式で表すと，

$$
\begin{aligned}
k_{i j} & =\frac{1}{2} \int_{0}^{L}\left[E I(x)\left\{\frac{\partial^{2} w_{i j}(x)}{\partial x^{2}}\right\}^{2}\right. \\
& \left.+\int_{x}^{L} \rho A(x) g d x\left\{\frac{\partial w_{i j}(x)}{\partial x}\right\}^{2}\right] d x, \\
k_{v i j} & =\frac{1}{2} \int_{0}^{L} k_{v j}(x) w_{i j}^{2} d x, \\
m_{i j} & =\frac{1}{2} \int_{0}^{L} \rho A(x) w_{i j}^{2}(x) d x .
\end{aligned}
$$

となる.ここで, $\omega_{i j}^{2}=\lambda_{i j}$ とおくと，

$$
\omega_{i j}=\sqrt{\frac{\tilde{k}_{i j}}{\tilde{m}_{i j}}}=\sqrt{\frac{k_{i j}+k_{v i j}}{m_{i j}}},
$$

であり,式 (14)は，

$$
\omega_{i j}^{2} m_{i j}-k_{i j}=k_{v i j}
$$

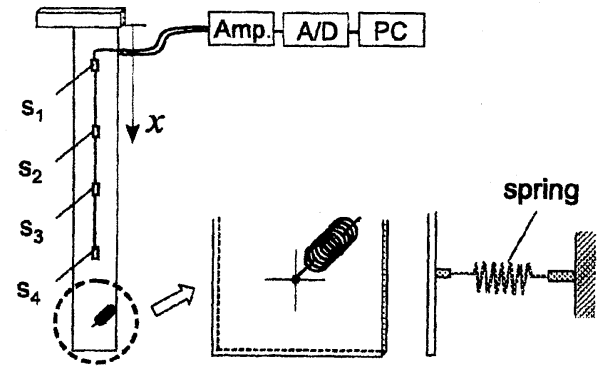

Fig. 1 Experimental setup for variable stiffness system

ここで, 右辺には可変構造パラメータ, 左辺には $E I(x)$, $\rho A(x)$ が含まれる。従って, 式 (15) に基づき, $E I(x)$, $\rho A(x)$ などを同定可能であると考えられる.

片持ち梁が一様であると仮定できるとき, 曲げ剛性 と単位質量は定数となり,式 (15) は以下のように書き 換えることができる.

$$
\begin{array}{r}
\rho A \omega_{i j}^{2} \int_{0}^{L} w_{i j}^{2}(x) d x-E I \int_{0}^{L}\left\{\frac{\partial^{2} w_{i j}(x)}{\partial x^{2}}\right\}^{2} d x \\
-\rho A g \int_{0}^{L}(L-x)\left\{\frac{\partial w_{i j}(x)}{\partial x}\right\}^{2} d x \\
=\int_{0}^{L} k_{v j}(x) w_{i j}^{2}(x) d x .
\end{array}
$$

式 (16) より, $m$ 通りの可变構造パラメータ変化を用い た場合, 以下のような行列方程式にまとめられる。

$$
\left[\begin{array}{cc}
a_{i 1} & b_{i 1} \\
a_{i 2} & b_{i 2} \\
\vdots & \vdots \\
a_{i m} & b_{i m}
\end{array}\right]\left\{\begin{array}{l}
\rho A \\
E I
\end{array}\right\}=\left\{\begin{array}{c}
c_{i 1} \\
c_{i 1} \\
\vdots \\
c_{i m}
\end{array}\right\} .
$$

ここで, $a_{i j}, b_{i j}, c_{i j}$ は，それぞれ既知量と計測値から与 えられ,

$$
\begin{aligned}
& a_{i j}=\omega_{i j}^{2} \int_{0}^{L} w_{i j}^{2}(x) d x-g \int_{0}^{L}(L-x)\left\{\frac{\partial w_{i j}(x)}{\partial x}\right\}^{2} d x \\
& b_{i j}=-\int_{0}^{L}\left\{\frac{\partial^{2} w_{i j}(x)}{\partial x^{2}}\right\}^{2} d x \\
& c_{i j}=\int_{0}^{L} k_{v j}(x) w_{i j}^{2}(x) d x .
\end{aligned}
$$

\section{4. 自己同定可能性指粟を用いた自己同定実験}

本節では, 柔軟片持ち梁の同定問題を取り上げ, まず 構造パラメータ同定実験を行う. 次に, 可変剛性による モード特性変化量を, 提案した指標により定量的に評 価し, 同指標値と実験結果の誤差特性の関係を考察す ることにより，提案指標の有効性を検討する。 
Table 1 Condition of data acquisition

\begin{tabular}{lc}
\hline Number of data for FFT, $N$ & 32768 \\
Sampling interval, $\Delta t[\mathrm{sec}]$ & 0.005 \\
Frequency resolution, $\Delta f[\mathrm{~Hz}]$ & 0.0061 \\
Cutoff frequency of filter, $f_{c}[\mathrm{~Hz}]$ & 30 \\
Analysis interval, [sec] & $30 \leq t \leq 60$ \\
\hline \hline
\end{tabular}

\begin{tabular}{ll}
\multicolumn{1}{c}{ Table 2 Parameters for flexible beam } \\
\hline Length, $L[\mathrm{~m}]$ & 1.80 \\
Width, $b[\mathrm{~m}]$ & $1.50 \times 10^{-1}$ \\
Thickness, $h[\mathrm{~m}]$ & $1.56 \times 10^{-3}$ \\
Density, $\rho\left[\mathrm{kg} / \mathrm{m}^{3}\right]$ & $2.70 \times 10^{3}$ \\
Young's modulus, $E\left[\mathrm{~N} / \mathrm{m}^{2}\right]$ & $6.83 \times 10^{10}$ \\
\hline
\end{tabular}

\section{$4 \cdot 1$ 実験装圆 図 1 に可変㓮性システムの実験} 装置構成を示す，実験装置は，柔軟梁，4個の昰ゲ一 ジ (共和電業: KFG-5-12-C1-23, 各 2 ゲージ法), ブリッ ジ回路 (共和電業: DB-120P), 動歪アンプ 4 台 (共和電 業: DPM-711B), A/D, D/A 変換器を搭載したインター フェース部に用いる, Real-Time-Interface (dSPACE 社: DS1103), データ取得解析用 PCなどから構成される.ま た, 実時間でのデータ取得には, ControlDesk (dSPACE 社: Version 2.1) を用いる. 実験装置の柔軟梁の特性は, 表 2 に示されたものを用いる。

実験データの取得に関するパラメータを表 1 に示す. 表 1 中のフーリエ変掺データ数 $N$ は、計測装置でサン プルした $6001(=30 / \Delta t+1)$ 個の歪のデジタルデータ に, 周波数分解能を向上させるためにゼロを加えた後 のデータ数である. 歪ゲージ 4 点の各出力電圧は動歪 アンプにより増幅され A/D変換して PCに取り込まれ る. 歪ゲージは, 梁の固定端側からの距離, 0.1, 0.6, 0.9, $1.3 \mathrm{~m}$ の 4 䇴所, またそれぞれを, $S_{1}, S_{2}, S_{3}, S_{4}$ と定義 する。

本実験では, 式 (6)における制御入力として用いる付 加バネは, 初期值を含め三通り $(m=3)$ に変化可能とし, それぞれ, $k_{v 1}=0, k_{v 2}=9.7 \pm 0.4, k_{v 3}=18.5 \pm 0.7 \mathrm{~N} / \mathrm{m}$ とする.なお, $k_{v 2}, k_{v 3}$ の誢差範团は, 実験で用いた片持 梁の静的曲げ試験結果の誤差範囲に基づき定めた(11).

4.2 モード形状の補間前節で導いた柔軟梁の 構造パラメータ同定法では, 梁の固有值ならびに固有 ベクトルを観測値として用いる。しかしながら,梁の 全頒域に分布するセンサを用いたモード形状の厳密な 計測は困難であり，離散点の計測値から推定する必要 がある. 本実験では, 3 次スプライン補間法を用いて計 測可能な 4 点の歪及び片持ち梁の境界条件からモード 形状を推定しこれを同定における観測值として用いる 方法を採用する.よって, 計測点 4 点と先端を含めた 5
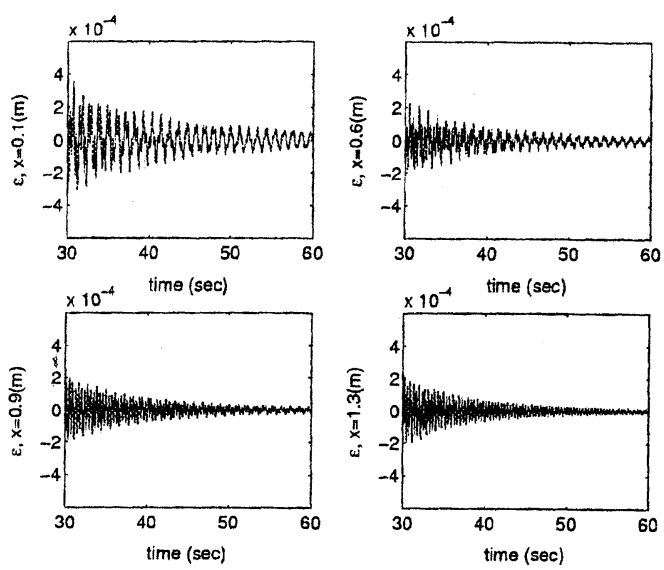

Fig. 2 Time history of strain at four sensor locations of flexible beam with variable stiffness $(j=2)$
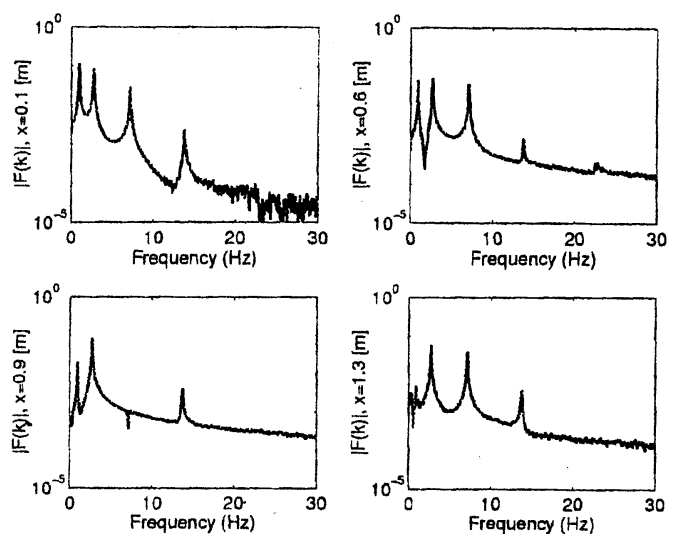

Fig. 3 Fourier spectrum, $|F(k)|$ calculated for time history of strain data by DFT, $(j=2)$

点の歪分布から 3 次スプライン補間によって梁の長さ 方向に詳細な離散データを得る。ここでは, 梁の長手 方向, $5 \mathrm{~mm}$ 間隔で計 361 点のスプライン補間を行い モード形状として用いる．以下にこのようなモード形 状推定を用いた数值解析及び実鈳結果を示す.

4.3 実験結果梁の微小変位を仮定した定式化 を行ったため, 梁は面外方向への弱い衝撃により加振 を行った. 加振点は, 低次振動モードを励起するために 梁の自由端部付近とした，ただし，今回の実験ではモー ド特性の計測が目的であるのでインパルスハンマ等に よる加振力の計測は行っていない. なお, 付加バネ, $k_{v 3}$ は, 図 1 のように梁に取り付けたバネの反対面にもう 一つ付加バネを取り付けることにより可変㓮性を模擬 した. 


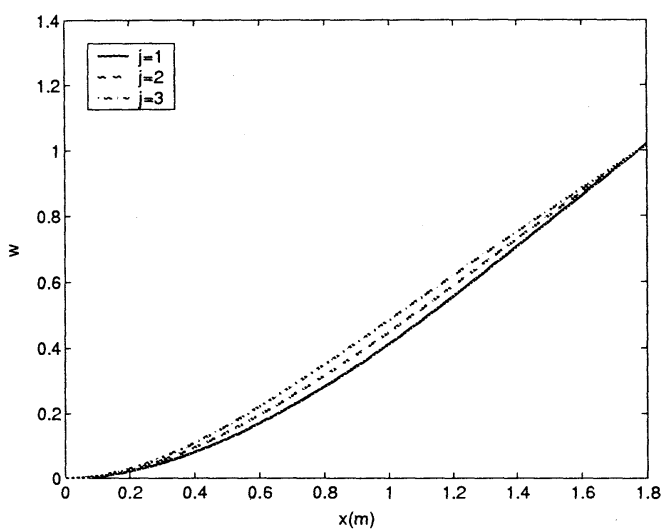

Fig. 4 Mode shape of 1st mode for flexible beam with variable stiffness

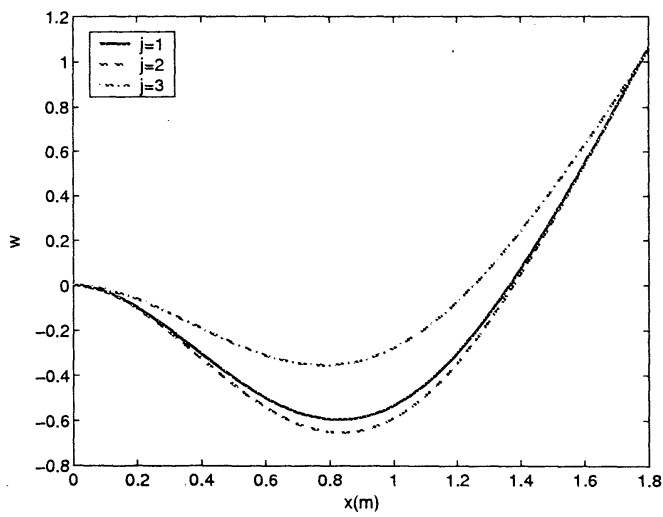

Fig. 5 Mode shape of 2nd mode for flexible beam with variable stiffness

実験により計測された自由振動波形の例として,図 2 に, 梁の $x=1.525 \mathrm{~m}$ の位置に付加バネ, $k_{v 2}$ を付加した 時の歪ゲージより計測されたの歪の振動時刻歴を示す. また, 各センサの時刻歴データ $y[n](n=1,2, \cdots, N)$ に 対し, 離散フーリエ変換 $F(k)=\sum_{n=0}^{N-1} y[n] e^{-j(2 \pi / N) k n}$ を 行い,その絶対值, $|F(k)|$ を図 3 に示した. フーリエ変 換を行う前に, エイリアシング対策として動歪アンプ で $30 \mathrm{~Hz}$ のカットオフ周波数の 2 次バタワースフィル タをかけた. また, リーケージ誤差への対策として, 指 数空を用いた.ここで用いた指数空は, 指数空の值が, 計測開始時刻 $(t=0 s)$ の時に 1 , 計测終了時刻 $(t=30 s)$ の時に 0.05 となるように設定した. なお, 上記に示し た図 2 は指数空を乗じる前の波形である.

得られたフーリエ振幅と位相から, 付加バネによって 変化する 1 次, 2 次モード形状を求めた結果を図 4,5 に
Table 3 Dominant frequency [Hz] and mode number of each sensor: Case A and Case B

\begin{tabular}{cccc}
\hline Sensor No. & $j=1$ & $j=2$ & $j=3$ \\
\hline$S_{1}$ & $2.69(2)$ & $0.93(1)$ & $1.17(1)$ \\
$S_{2}$ & $2.69(2)$ & $2.71(2)$ & $7.14(3)$ \\
$S_{3}$ & $2.69(2)$ & $2.71(2)$ & $2.74(2)$ \\
$S_{4}$ & $2.69(2)$ & $2.71(2)$ & $7.14(3)$ \\
\hline
\end{tabular}

Table 4 Dominant frequency $[\mathrm{Hz}]$ of each sensor with constraint, $\left(f_{i j} \leq 4.9 \mathrm{~Hz}\right)$ : Case $\mathrm{C}$

\begin{tabular}{cccc}
\hline \hline Sensor No. & $j=1$ & $j=2$ & $j=3$ \\
\hline$S_{1}$ & $2.69(2)$ & $0.93(1)$ & $1.17(1)$ \\
$S_{2}$ & $2.69(2)$ & $2.71(2)$ & $1.16(1)$ \\
$S_{3}$ & $2.69(2)$ & $2.71(2)$ & $2.74(2)$ \\
$S_{4}$ & $2.69(2)$ & $2.71(2)$ & $2.75(2)$ \\
\hline \hline
\end{tabular}

それぞれ示した.ここで,歪分布から求まる $d^{2} w(x) / d x^{2}$ を累積台形積分を 1 回行い撓み角 $d w(x) / d x, 2$ 回行う ことにより撓み $w(x)$ を計算した.

上記の手順により, 制御入力, $j=1,2,3$ の各場合に 推定した卓越周波数と卓越モードの次数を表 3 から表 5 にまとめた. 各表中の括弧内はモード次数を表す.こ れらの固有振動数の推定は, 以下のように行った。ま ず, 実験で用いた 4 つの歪みセンサ, $S_{1}$ から $S_{4}$ のうち, 一つを「独立センサ」, 他を「従属センサ」と定義す る.独立センサにより計測した振動データのスペクト ルから振幅が最大值となる周波数を推定し，これを独 立センサにおける卓越モードと定義する. 4 つのセン サにおいて剛性を 3 通りに変化させるごとに卓越モ一 ドを推定すると, 計 12 通りの卓越周波数が推定され る. 当然, 固有振動数の推定法は他の方法でも良い.

表 3 では, 計 12 通りの振動数のうち, $S_{1}$ を独立セン サとした場合のみ, $j=2, j=3$ のとき 1 次モードと考 えられる周波数が卓越した. その他, $S_{2}$ から $S_{4}$ センサ では, 何れも 2 次または 3 次モードが卓越した. 次に, 表 4 は, $0 \mathrm{~Hz}$ から $100 \mathrm{~Hz}$ の全周波数帯域を固有特性 推定の解析対象带域とせず, $0 \mathrm{~Hz}$ から $4.9 \mathrm{~Hz}$ のみを解 析帯域とする周波数帯域に拘束条件を与えた場合, 及 び表 5 は, $0 \mathrm{~Hz}$ から $1.8 \mathrm{~Hz}$ を解析帯域の拘束条件とし た場合の各センサにおける卓越した振動数とモード次 数の推定值である. $1.8 \mathrm{~Hz}$ の解析帯域に関する境界は, 実験で得られたフーリエスペクトルから推定される 1 次, 2 次固有振動数のおよその平均值, また, $4.9 \mathrm{~Hz}$ は, 2 次, 3 次固有振動数のおよその平均值からそれぞれ定 めた。 
Table 5 Dominant frequency $[\mathrm{Hz}]$ of each sensor with constraint, $\left(f_{i j} \leq 1.8 \mathrm{~Hz}\right)$ : Case $\mathrm{D}$

\begin{tabular}{cccc}
\hline \hline Sensor No. & $j=1$ & $j=2$ & $j=3$ \\
\hline$S_{1}$ & $0.62(1)$ & $0.93(1)$ & $1.17(1)$ \\
$S_{2}$ & $0.62(1)$ & $0.93(1)$ & $1.16(1)$ \\
$S_{3}$ & $0.62(1)$ & $0.93(1)$ & $1.16(1)$ \\
$S_{4}$ & $0.62(1)$ & $0.93(1)$ & $1.16(1)$ \\
\hline \hline
\end{tabular}

Table 6 Identification result with variable stiffness from experimantal data (4 sensors output)

\begin{tabular}{ccc}
\hline \hline Case & $\rho A[\mathrm{~kg} / \mathrm{m}]$ & $E I\left[\mathrm{Nm}^{2}\right]$ \\
\hline Case A & $0.65 \pm 0.03$ & $3.42 \pm 0.14$ \\
Case B & $0.01 \pm 0.001$ & $0.04 \pm 0.002$ \\
Case C & $0.49 \pm 0.02$ & $2.62 \pm 0.11$ \\
Case D & $0.65 \pm 0.03$ & $3.33 \pm 0.14$ \\
\hline Exact & $0.64 \pm 0.003$ & $3.27 \pm 0.11$ \\
\hline \hline
\end{tabular}

表 6 に 4 通りの異なる係数行列構成の場合の各同定 結果を示す.ここで各同定結果の標準偏差は, 本実験 において含まれる様々な誤差要因の中で, 最大の誤差 範囲を含む付加バネ, $k_{v 2}$ の誤差率と等しい $4.1 \%$ を仮 定した. その他の誤差要因には, 梁の長さ, 板厚, 周波 数分解能, などが考えられるが, 何れのパラメータの誤 差率も付加バネの誤差範囲のオーダーよりも小さかっ た.ただし, 後述の考察で述べるように, スプライン補 間によるモード形状補間における誤差は, モード次数 に依存して大きく変化するため, 実験誤差とは区別し て扱う。

表 6 において, Case A は, $S_{1}$ を独立センサとして制 御入力変化ごとのモード形状を推定した場合, Case B は, $S_{1}$ から $S_{4}$ 全てのセンサをそれぞれ独立センサとし て用いた場合である.また, Case C 及び Case D は, 解 析帯域にそれぞれ, $4.9 \mathrm{~Hz}, 1.8 \mathrm{~Hz}$ 以下の拘束条件を加 えた場合において, 全てのセンサを用いたときの同定 結果である.

Case A 及び Case D こ二つの場合には, 同定精度が 同程度に高く, Case C では誤差は比較的大きいが物理 的には妥当な䛊差内で同定されたが, Case B では妥当 な結果が得られなかった. Case B のみ 3 次モードの固 有值, 固有ベクトルを用いていることから, 1 次, 2 次 モードの固有值, 固有ベクトルの変化を用いた場合に は, $\rho A, E I$ の同定が可能であることが明らかになった. なお, 最も精度の高い Case A, Case D の場合にも, 曲 げ剛性は, 実際よりも大きく同定された。この原因は 定式化において無視したバネの質量, バネ固定用のボ
Table 7 CSI, ECSI and Condition number for lower three modes of variable stiffness system

\begin{tabular}{cccc}
\hline & $i=1$ & $i=2$ & $i=3$ \\
\hline CSI & $1.2 \mathrm{e}-03$ & $1.2 \mathrm{e}-03$ & $2.3 \mathrm{e}-05$ \\
ECSI & $1.6 \mathrm{e}-02$ & $6.1 \mathrm{e}-06$ & $5.8 \mathrm{e}-08$ \\
Cond (A) & 53.5 & 704.4 & 7201.5 \\
\hline \hline
\end{tabular}

Table 8 Identification result with variable stiffness from incomplete measurement (4 sensors output)

\begin{tabular}{ccc}
\hline Mode, $i$ & $\rho A[\mathrm{~kg} / \mathrm{m}]$ & $E I\left[\mathrm{Nm}^{2}\right]$ \\
\hline 1 & 0.615 & 3.119 \\
1,2 & 0.618 & 3.172 \\
$1,2,3$ & $(-0.0004)$ & $(-0.007)$ \\
\hline Exact & 0.635 & 3.275 \\
\hline \hline
\end{tabular}

ルトの質量などに働く重力による付加剛性の影響であ ると考えられる. また, Case B の結果に示されたよう に, 3 次モードの推定結果を係数行列に含めた場合に は, 妥当な精度の同定が行えなかった。

以上のように, パラメータ同定精度は明らかに用い るモードの組み合わせに依存していることが示された. 本研究で提案する二つの指標值を用いて, これらの誤 差特性を定量的に説明することができれば, 提案指標 の妥当性を示すことができる.

次節では, そのような観点から実験結果と対応した 数值実験を行うことによって, 提案指標と同定精度の 関係を考察する.

4.4 自己同定可能性指標による考察こここでは, 実験と同様に, 付加バネと柔軟梁からなる可変剛性シ ステムの有限要素モデルを用いて自己同定実験を行い, 前述のように用いる振動モードによって同定誤差が変 化する要因について, 提案指標を用いて考察する. 梁 の有限要素モデルは, オイラー梁要素を用いて, 実験精 度に対し十分な 36 要素数とした. また, 鉛直に固定さ れた梁への重力による付加剛性の効果も考慮した. 梁 に固定する三通りの付加バネの值は,それぞれ $k_{v 1}=0$, $k_{v 2}=9.7, k_{v 3}=19.4 \mathrm{~N} / \mathrm{m}$ とし, これらのバネ付加位置 は, $x=1.5 \mathrm{~m}$ とした. 固有值, モード形状は実験と同じ $<, 4$ 点の離散的な歪値に対し 3 次スプライン補間を 用いて推定した. 表 7 は, 付加バネによる各モードの 可制御性の指標として提案した CSI, ECSI，ならびに 式 (17) の係数行列の条件数を計算した結果である. 表 7 から, 実験装置のモード形状の CSI は, 3 次モードが 最も小さく, 1 次, 2 次は同程度であった.一方, 式 (17) の係数行列の ECSI は, 1 次モードが相対的に大きく, 


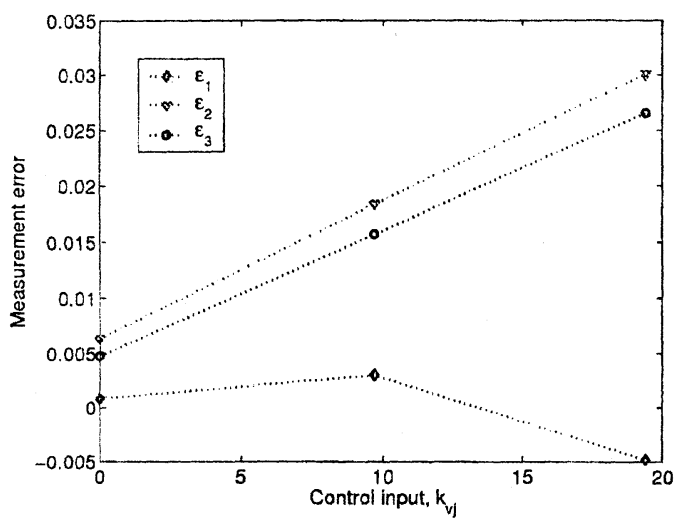

Fig. 6 Measurement error of first mode due to spline interpolation

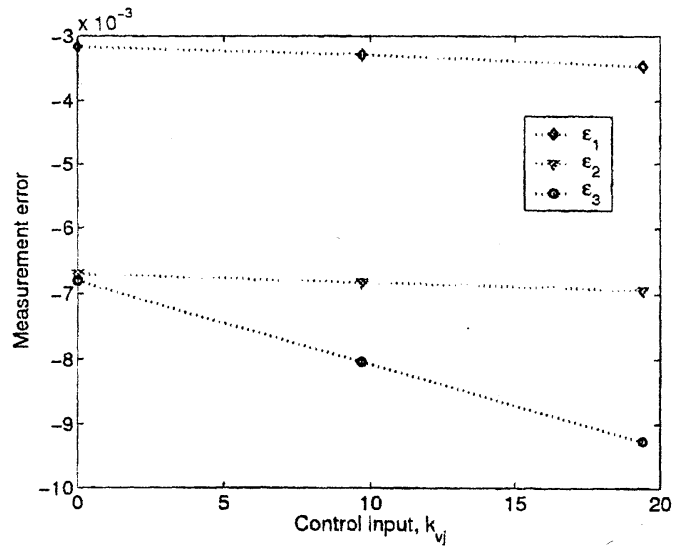

Fig. 7 Measurement error of second mode due to spline interpolation

2 次に比較し 3 析, 3 次に比較し 5 桁の差があることが 明らかになった. 各モードの条件数は, 1 次モードが最 も小さく, 2 次は 1 次の約 16 倍, 3 次は約 140 倍であっ た.これらから, 1 次, 2 次モードはモード形状変化の 独立性を表す CSI は同程度であるが, 未知パラメータ の係数行列に対忘した ECSIについては, 2 次よりも 1 次の方が良好であるといえる，また，3次モードはCSI， ECSI 何れも小さく，モード形状の可制御性が低く,か つ観測誤差に対して感度が高いといえる。

式 (17) を構成するために, $i=1$ のときは, $(3 \times 2)$ の係 数行列, $i=1,2$ のときは, $(6 \times 2)$ の係数行列, $i=1,2,3$ のときは, $(9 \times 2)$ の係数行列を構成する. 表 8 に示され たように, 実験に対応した 4 点計測によるモード形状 推定の場合には, 1 次モードのみ, 1 次, 2 次のみのそれ ぞれの質量,剛性の同定誤差は, それぞれ約 3\%,約 5\%

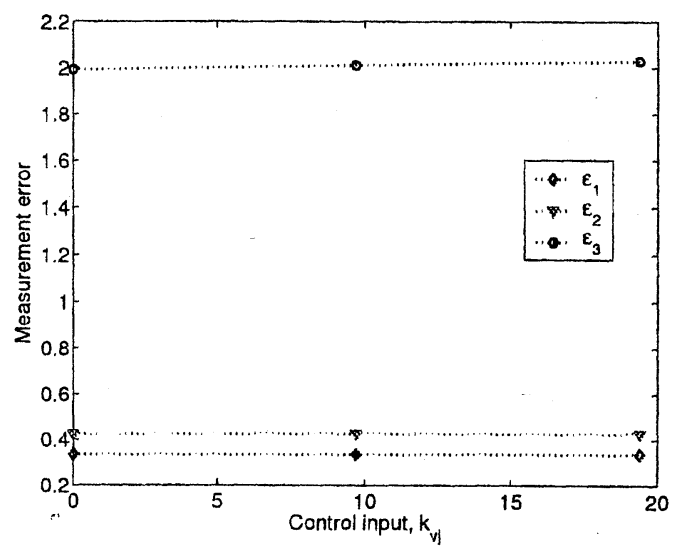

Fig. 8 Measurement error of third mode due to spline interpolation

以内であった. しかしながら，1次から 3 次モードを用 いた場合には,物理的に妥当でない同定結果となった。 従って, ECSI が大きく,未知構造パラメータの係数行 列の条件数が小さいモードでは精度良い自己同定が可 能であるが,そうでない場合には同定精度の低下が起 こることが確詔され，これらは実験結果と整合性がと れている.

さらに, 各モードごとに, 式 (17) に代入する複数の 積分值の比較を行った. 图 6-8 に次式で定義する無次 元俱差を各モード毎に解析した結果を示す。

$$
\begin{aligned}
& \varepsilon_{1}=\frac{\int_{0}^{L}\left\{\frac{\partial^{2} \tilde{w}_{i j}(x)}{\partial x^{2}}\right\}^{2} d x}{\int_{0}^{L}\left\{\frac{\partial^{2} w_{i j}(x)}{\partial x^{2}}\right\}^{2} d x}-1, \\
& \varepsilon_{2}=\frac{\int_{0}^{L}(L-x)\left\{\frac{\partial \tilde{w}_{i j}(x)}{\partial x}\right\}^{2} d x}{\int_{0}^{L}(L-x)\left\{\frac{\partial w_{i j}(x)}{\partial x}\right\}^{2} d x}-1, \\
& \varepsilon_{3}=\frac{\int_{0}^{L} \tilde{w}_{i j}^{2}(x) d x}{\int_{0}^{L} w_{i j}^{2}(x) d x}-1 . \quad(j=1,2,3)
\end{aligned}
$$

ここで, $\tilde{w}_{i j}(x), w_{i j}(x)$ はそれぞれ，スプライン補間によ る近似モード形状, 真值である. 図6,7のように, 1 次 モードは最大 $3 \%$ 程度, 2 次モードは最大 $1 \%$ 程度であ るのに対し, 3 次の誤差はかなり大きく,特に暁みの積 分值の俱差, $\varepsilon_{3}$ が大きいことが示された，これらの結 果から, 観測俱差に対し最も感度の低い 1 次モードの 観測精度が最も高く,2次モードは，観測精度のみであ れば, 1 次モードよりも高精度である。一方, 3 次に関し ては, 锶測諟差に対して感度が高いうえに, 襩測俱差も 大きいため同定諆差が増加したものと考えられる.た だし，各モードのモード形状推定精度はセンサ配置に 依存しているため, センサ配置により本考察とは異な 
る䛊差率になると考えられる.

以上の考察から, 本研究で提案する自己同定可能性 指標を用いて,あらかじめ可変構造パラメータの自己 同定能力の程度を把握することが可能になり,適応構 造システムの設計ならびに自己同定において要求され る振動データの観測精度を把握できる可能性が示され た。ただし、実験から推定したモード形状を用いて自己 同定可能性指標を計算する場合には, モード形状の推 定精度を向上させることが重要である.特に高次モー ドの場合には,一般にモード形状の推定が困難となり， 十分な数の計測点数とその適切な配置が要求される.

\section{5. 結 論}

自己同定を行う場合に, 自己同定の容易さを定量的 に評価する二つの指標值の提案を行った.一つは固有 ベクトルの独立性に基つく自己同定可能性指標であり， もう一つは未知構造パラメータに係る係数行列の列べ クトルの独立性指標である抗張自己同定可能性指標で ある. 次に, 柔軟片持ち梁と付加バネからなる可变㣚 性システムの実験装置を棈築し, 可变剛性による構造 パラメータ同定を実証した. また, 有限要素法により 実験と対応する数值実験を行い, 実験で生じた同定誤 差と提案指標値との定量的関係を考察した. その結果, 提案した自己同定可能性指標が大きい程, 同定精度の 向上が可能であること,及び従来, 数値実験でのみ示さ れてきた可変構造パラメータを用いた自己同定の可能 性が本実験により実証された。

\section{文献}

(1) Miura, K., Furuya, H., Adaptive Structure Concept for Future Space Applications, AIAA I., Vol. 26, No.8 (1988), pp.995-1002.

(2) Friswell, M.I., Mottershead, J.E., Finite Element Model Updating in Structural Dynamics, (1995), Kluwer Academic Publishers.

(3) Ricles, J.M., Kosmatka, J.B., Damage Detection in Elastic Structures Using Vibratory Residual Forces and Weighted Sensitivity, AIAA Journal, Vol. 30, No.9 (1992), pp.2310-2316.

(4) Kabe, A.M., Stiffness Matrix Adjustment Using Mode Data, AIAA journal, Vol. 23, No.9 (1985), pp.1431-1436.

(5) Okuma, M., Shi, Q., Oho, T., Development of The Experimental Spatial Matrix Identification Method (Theory and Basic Verification With A Frame Structure), Journal of Sound and Vibration, Vol. 219, No.1 (1999), pp.5-22.

(6) Nalitolela, N.G., Penny, J.E.. Friswell, M.I., A Mass or Stiffness Addition Technique for Structural Parameter Updating, International Journal of Analytical and Experimental Modal Analysis, Vol. 7, (1992), pp.157168.
(7) Senba, A., Furuya, H., Identifiability and Limitation of Self-Identification of Adaptive Structures by Variable Matrices Method, Journal of the Japan Society for Aeronautical and Space Sciences, Vol. 52, No. 609(2004), pp.479-486.

(8) Onoda, J., Endo, T., Tamaoki, H., Watanabe, N., Vibration Suppression by Variable-Stiffness Members, AlAA Journal, Vol. 29, No.6 (1991), pp.977-983.

(9) Furuya, H. and Kobori, A, Suppression of Multiple Modes Vibration of Flexible Structures with Adaptive Gyroscopic Damper System, 10th Int. Conference on Adaptive Structures and Technologies, Technomic Publishing, (1999), pp.127-134.

(10) Senba, A., Furuya, H., Self-Identification of TwoDimensional Adaptive Structures with Variable Geometric Parameters, Space Technology Japan, The Japan Society for Aeronautical and Space Sciences, Vol. 5, (2006), pp.1-7.

(11) Senba, A., Self-identification of Adaptive Structure Systems Using Variable Structural Parameters, Doctoral dissertation, Tokyo Institute of Technology, (2006), pp.214-215. 